\title{
Trabalho compulsório e escravidão indígena no Brasil imperial: reflexões a partir da província paulista
} Compulsory Labor and Indigenous Slavery in Imperial Brazil: Reflections from the Province of São Paulo

Soraia Sales Dornelles ${ }^{\star}, 1$

\section{Resumo}

Este artigo trata de um tema ainda muito pouco explorado na historiografia, o trabalho indígena no Brasil imperial, principalmente posterior à década de 1840 , a partir das alterações da legislação indigenista de 1845 (Regulamento acerca das Missões de Catequese e Civilização de Índios) e imperial de 1850 (Lei de Terras). Em desacordo com a falácia já em voga no século XIX, de que os índios não se prestavam ao trabalho, observamos como essas populações atuaram nos mais diversos ramos econômicos: agricultura, pecuária, atividades extrativistas, serviços domésticos, abertura de estradas e realização de obras públicas, eles prestaram serviços de navegação, foram guias e soldados, entre tantas outras atividades. Sua cooptação nem sempre ocorreu com observância aos critérios legais, e essas populações muitas vezes foram submetidas à escravidão ou a formas análogas de coerção. Essa verdade era conhecida pelas autoridades do período e, também,

\section{Abstract}

This article casts new light on indigenous work in Brazil's Second Empire in the wake of the Indigenous legislation of 1845 (Regulation on the Missions of Catechesis and Indigenous Civilization) and the Land Law of 1850. Contrary to the widespread belief in the nineteenth century that Indians did not lend themselves to work, these populations' labor weighed upon the most varied economic branches: agriculture, cattle raising, extractive activities, domestic services, opening of roads, public works, and navigation services. Indians served as guides, soldiers, sailors, and servants, among many other roles. Yet, their co-optation did not always occur in compliance with legal criteria, which led to these populations' subjection to slavery and other forms of coercion. This was a fact known by the authorities of the period, but also by the Empire's different indigenous groups, who negotiated and sought to impose,

\footnotetext{
* Universidade Federal do Maranhão (UFMA), Departamento de História. São Luís, MA, Brasil. soraiasdornelles@gmail.com <http://orcid.org/0000-0002-1760-4041>
} 
pelos diversos grupos indígenas do Império, que negociaram e procuraram impor, na medida do possível, suas condições para as relações de trabalho.

Palavras-chave: trabalho; trabalho compulsório; escravidão indígena. as far as possible, their own conditions for labor relations.

Keywords: work; illegal enslavement; indigenous enslavement.

\section{O TRABALHO DOS ÍNDIOS E A FORÇA DO COSTUME}

Em maio de 1853, o Diretor Geral dos Índios de São Paulo, brigadeiro Joaquim José Machado de Oliveira, atendeu uma peculiar demanda da presidência provincial: foi solicitada a elaboração de uma tabela de prêmios, baseada nos valores pagos pelos índios selvagens que "são prisioneiros das escoltas que contra eles se expedem, ou dos próprios índios”. O governo sugeriu que essas informações fossem averiguadas com os diretores dos aldeamentos, mas eles não responderam ao chamado. Assim, Machado de Oliveira formulou, ele próprio, com o auxílio do barão de Antonina e do fazendeiro José Elias de Carvalho, uma tabela. Ela apresentou as quantias que poderiam ser utilizadas no "resgate dos índios selvagens que se encontravam prisioneiros". ${ }^{2}$ A variação dos preços se dava por sexo e idade, sendo mais valorizados os homens entre 20 e 30 anos, ao custo de 60 mil réis.

Acontece que, no mês anterior, o Diretor Geral dos Índios tinha escrito à mesma presidência a respeito do que considerou um "bárbaro e imoral costume": a prática de comprarem-se como escravos os índios ditos selvagens, e mantê-los nas fazendas e povoações que ficavam nas matas a Oeste da província. Por mais que o brigadeiro considerasse o tráfico de índios um ato atroz, praticado, "aceito e alimentado pela cobiça e imoralidade dos civilizados e cristãos”, não pensou que as expedições de apreensões deveriam ser findadas, "dado o caso de sermos acometidos ou ameaçados pelos índios selvagens". Era preciso livrar-se dos excessos, e fazer algo dos infelizes que, porventura, fossem trazidos à civilização por seus inimigos, mas sem fazer escravos a "indivíduos que nasceram livres".

A solução por ele apresentada foi autorizar aos Juízes de Órfãos das vilas próximas aos sertões "o resgate dos índios selvagens apresentados na condição de prisioneiros”, concedendo-lhes os recursos necessários. Também sugeriu que "os indivíduos que forem assim resgatados sejam imediatamente enviados com uma escolta para o aldeamento de S. João Baptista da Faxina, onde serão entregues ao respectivo capelão". Por fim, pensou ser justa a indenização dos 
possuidores de escravos índios, às custas da quota anual da Catequese e Civilização. ${ }^{3}$

A questão não era nova. Em 1847, o Diretor Geral, conclamando as diretrizes expostas no Regulamento acerca das Missões e Catequese de Índios $(1845),{ }^{4}$ já havia solicitado à presidência providências a respeito dos índios escravizados. Alegou que, em muitos distritos das cidades de Itu e Sorocaba, bem como das vilas de Capivari, Porto Feliz e Pirapora, havia famílias de índios "oriundas de outras, que em épocas remotas foram à força extraídas das matas e reduzidas ao cativeiro". Essa "numerosa descendência" estava sujeita ao cativeiro ilegal, mas sofria também de outros "antigos e inveterados preconceitos, em que sempre se teve esta classe de Brasileiros" e encontravam-se a vagar, errantes, nos distritos mencionados. ${ }^{5}$ Se por parte das autoridades provinciais houve uma forte tendência em descaracterizar as populações de antigas regiões de aldeamentos coloniais do critério étnico, considerando-os como parte da massa comum da população, por outra feita, os documentos também revelaram a facilidade com que essas mesmas pessoas poderiam ser tomadas como indígenas e, assim, passíveis de escravização ilegal ou precarização de suas condições de trabalho. ${ }^{6}$

Note-se a força do costume perante a lei. Em 1847, haviam-se passado 16 anos da promulgação da lei imperial que estipulou a ilegalidade da escravidão indígena, 22 quando a tabela com os valores para resgate foi criada. A lei de 1831 estipulava a revogação das Cartas Régias de 1808, libertando os índios do regime de escravidão e impondo um regime tutelar, considerando-os como menores, mantidos sob os cuidados dos Juízes de Órfãos (Cunha, 1992a, p.69, $74-75,79-80)$. Estes poderiam tanto recorrer ao Tesouro para o sustento dos índios ou depositá-los onde tivessem salários ou aprendessem ofícios fabris. Tais autoridades eram responsáveis pelo zelo no cumprimento de contratos de todos os escravos libertos indígenas e "notadamente, aos africanos libertos", que livres pela primeira lei do fim do tráfico de africanos, atracavam no Brasil, e acabavam escravizados. O poder da distribuição para o trabalho que o ofício de Juiz de Órfãos continha ficava evidente pelo rápido enriquecimento que ocorria com seus ocupantes, não sendo permitido que o mesmo cidadão realizasse essa função por mais de 4 anos (Cunha, 1992a, p.24). Caberia a ele "evitar que se escravizasse de fato gente livre que tinha poucos meios de se defender por ignorar a língua e os costumes do país: este era o caso dos africanos livres e dos índios não aldeados" (Amoroso, 1998, p.5). Pelo artigo $6^{\circ} \mathrm{da}$ lei de 1831 ficava a cargo dos Juízes de Paz a tarefa de atentar para quaisquer abusos contra a liberdade dos índios. Mais tarde, em 1833, delegou-se também 
aos Juízes de Órfãos a tarefa da administração dos bens dos índios de seus municípios (Cunha, 1992a, p.156-157). Muitos foram os casos em que essas autoridades valeram-se desse dispositivo legal para arrendar e aforar as terras indígenas. Para o jurista Agostinho Marques Perdigão Malheiro, que em 1867 historicizou criticamente a escravidão (tanto africana quanto indígena), a lei de 1831 deveria pôr fim ao "sistema de terror" imposto sobre os índios, já que além de tê-los perseguido sob o modelo de bandeiras, impulsionador de ódios, também os sujeitara à escravidão "disfarçada em servidão temporária e mesmo indefinida” (Malheiro, 1867, p.124).

Por fim, Machado de Oliveira propôs a nomeação de um Diretor para remediar os males que recaíam sobre aqueles infelizes, indicando o advogado e deputado Tristão de Abreu Rangel, residente em Itu, para o cargo. Entretanto, o governo dizia-se desautorizado para aprovar a proposta conforme o Regulamento de 1845, fundamento legal que o Diretor Geral utilizou para justificar o pedido. Estavam colocadas na prática as consequências da ambiguidade e subjetividade dos dispositivos regentes das questões indígenas. Ambas autoridades buscavam no artigo $2^{\circ}$ do Decreto $n^{\circ} 426$ - que dizia ser competência do Diretor Geral propor à presidência provincial Diretores para os aldeamentos, e o Presidente o responsável por efetivar as nomeações -, respaldo para suas afirmativas.

Em outro documento, Machado de Oliveira explicou-se melhor e enfatizou a necessidade da criação de um aldeamento na região de Itu, para tutelar os índios que ali se encontravam escravizados, ou que "estão expostos a ser arrastados a esta condição". 7 E fez isso valendo-se do princípio da equidade jurídica, citando o exemplo da autorização concedida para a criação do aldeamento de Iguape, em janeiro daquele mesmo ano, que reuniu paridade em condições (famílias indígenas estacionadas nas redondezas e em liberdade instável). Com tais considerações, o brigadeiro obteve a aprovação da proposta, mas o aldeamento não saiu do universo das intenções. Como mais tarde defenderia Perdigão Malheiro, as antigas leis que permitiram e estimularam a escravidão dos índios fundamentaram também comportamentos, de onde originaram-se "vexames, cativeiros ilegais, e questões que ainda hoje têm sido levadas aos Tribunais" (Malheiro, 1867, p.131).

Alguns costumes praticados em relação às populações indígenas foram de longevidade impressionante, principalmente aqueles atrelados à coerção para o trabalho. O uso da expressão resgate, por exemplo, remonta aos tempos coloniais, mas continuava em uso em meados do século XIX. O resgate foi uma das formas legais de escravizar indígenas durante o período colonial. 
Constituía-se na compra de cativos feitos prisioneiros em guerras indígenas, que eram salvos de futuros rituais de antropofagia. "Presos à corda", esses indivíduos deveriam ser convertidos e civilizados, benefícios que justificavam sua escravização temporária ou permanente, justamente para satisfação do pagamento do seu valor de compra (Perrone-Moisés, 1992, p.127-128). Nos casos aqui apresentados, o uso da expressão resgate denota o pagamento de um valor para os possuidores de indígenas escravizados ilegalmente, devolvendo-lhes sua liberdade. Assim, a expressão cujas origens remontam aos tempos coloniais readequava-se às prerrogativas legais e interesses específicos de parte da elite política paulista no Oitocentos, permanecendo, contudo, conectada à condição escrava que as populações indígenas experimentaram no passado. ${ }^{8}$

Sabia-se que os índios constituíam boa parte da mão de obra das fazendas dos sertões paulistas em meados do século XIX. Arrecadados e contratados nos aldeamentos existentes, ou, simplesmente, escravizados, eram os braços das lavouras, os peões das estâncias, os trabalhadores das aberturas de estradas e de tantas outras sortes de serviços. Os interesses indígenas e dos proprietários muitas vezes se congregaram, pois os primeiros buscaram nos segundos a proteção que julgaram apropriada para sobreviver aos ataques realizados por seus inimigos nas matas, indígenas de outros povos ou não.

Em 1854, por exemplo, o senador Francisco Antonio de Souza Queiroz, casado com uma das filhas do senador Vergueiro, remeteu uma carta ao Diretor Geral dos Índios, ${ }^{9}$ informando sobre a chegada, meses antes, à fazenda Santa Izabel, no distrito de Pirassununga do município de Limeira, de "uma porção de índios selvagens, para mais de cem indivíduos os quais, passando-se por mansos" tinham se instalado nas terras da fazenda do comendador Soares Silva. No mesmo ano, o fazendeiro e Subdelegado da vila de Botucatu, José Joaquim Alves Machado, também recebeu em sua fazenda índios que "apareceram ali espontaneamente", "em consequência da perseguição que sofriam de outras hordas mais poderosas". O Subdelegado informou que os índios já estavam vestidos, sendo instruídos no plantio, que lhes haviam sido entregues ferramentas de trabalho, armas de fogo para a caça "à que são inclinadíssimos", e que de "tão animados", ao findar o plantio naquele ano iriam enviar ao mato "uma bandeira deles, a fim de trazerem para o aldeamento o resto da horda, que é muito grande". ${ }^{10}$

Esse tipo de empreendimento pode ser lido como um aldeamento particular, nascido da filantropia de fazendeiros e de interesses indígenas. Como consta no documento citado, os índios tinham suas preferências: as armas de fogo se motivaram a aceitar propostas para fixar-se e aderir aos projetos 
civilizatórios. $\mathrm{O}$ acesso às ferramentas de ferro e aos tecidos havia muito serviam de razão suficiente para concretizar aproximações, dando-nos pistas sobre o ponto de vista indígena na construção dessas relações. Esses objetos eram os mesmos que motivaram as investidas indígenas aos povoados, quando em seus assaltos costumavam carregá-los consigo. ${ }^{11}$ Já os fazendeiros obtinham um número expressivo de trabalhadores - "para mais de cem indivíduos", grandes hordas - cujas condições de trabalho traziam benefícios que justificavam a filantropia.

Para que os exemplos aqui apresentados não sejam tomados como uma exceção ou particularidade do caso paulista, tentemos ampliar a visão sobre a situação dos índios durante o Império no que concerne à importância de sua força de trabalho.

\section{O TRABALHO DOS ÍNDIOS E A "OBSERVÂNCIA DOS CRITÉRIOS LEGAIS POR PARTICULARES"}

As autoridades provinciais estiveram plenamente cientes sobre ser um dos fins do serviço de Catequese e Civilização dos Índios o interesse em aumentar o número da força de trabalho produtora, principalmente em tempos nos quais o governo via-se cada vez mais pressionado para abolir a escravidão africana e recorria à colonização estrangeira. Aproveitar os milhares de braços indígenas dispersos pelo interior era uma questão de grande relevância. A serventia dos índios como trabalhadores pode ser demonstrada em diferentes localidades do Brasil imperial.

Lidas em conjunto, as partes dos relatórios provinciais que trataram dos temas da Catequese e Civilização e da Colonização apontam para uma sensação geral de insatisfação perante os dois ramos do serviço público: nem se convencia e convertia os índios do império, nem se obtinha o suor dos estrangeiros nas proporções almejadas pelos produtores. Sobre ambas, muitas vezes se disse "que pouco desenvolvimento tem tido". Tanto colônias quanto aldeamentos se extinguiram por não alcançarem o êxito almejado, fazendo a lavoura "definhar à mingua de braços", conforme se pronunciavam os produtores e autoridades. Porém, foram inúmeros os serviços e ocupações que grupos distintos de indígenas exerceram durante o período imperial. Os relatórios presidenciais estão repletos de observações elogiosas ao seu emprego nos mais diversos ramos. ${ }^{12}$

Os índios foram mão de obra na abertura e manutenção de estradas, pelas quais transitou a produção nacional. Essas vias também foram importantes 
para o estabelecimento do povoamento dos interiores, facilitando o acesso a áreas remotas. Ayalla Oliveira Silva (2017, p.171-183) apresentou de maneira detalhada as complexas relações que envolveram a abertura de estradas e a mão de obra indígena, ao analisar documentos que trataram da abertura e conservação da estrada entre Ilhéus e Vitória da Conquista, sul da Bahia. Nesse caso, os índios Camacãs, Pataxós e Guerens, do aldeamento de São Pedro de Alcântara ou Ferradas (tanto os fixados no espaço do aldeamento quanto os ditos dispersos) foram responsáveis por esse serviço de caráter público por longos anos, pelo menos entre 1843 e 1871. A manutenção dos caminhos implicou a retirada assídua dos matos, que poderiam pôr em risco a existência do empreendimento. A presença dos indígenas ali garantia também a segurança dos transeuntes. A autora destacou que tanto a existência da estrada quanto a do aldeamento foram responsáveis por assegurar certo fluxo contínuo de recursos para a vila de Cachoeira de Itabuna, garantindo o sucesso da política imperial na região. Assim, houve uma estreita relação entre a aplicação das políticas indigenistas, as políticas de ocupação territorial e o acesso à mão de obra no sul da Bahia, onde, a partir do princípio do Oitocentos, a produção de cacau foi responsável pela expansão agrária e econômica. Os índios atuaram, naquele contexto, na viabilização estrutural do projeto pela abertura da estrada, mas também, na navegação dos rios, e como trabalhadores nas fazendas dos "frutos de ouro".

Os índios foram empregados no corte de madeiras, na edificação de prédios, nos serviços de guias em viagens, "outros até têm saído [do Alagoas] para a província de Pernambuco em demanda de trabalho a salário nas estradas de ferro". ${ }^{13}$ No anexo ao relatório da presidência alagoana de 1862, lê-se sobre a aptidão para estafetas que demonstraram os Cariris, por serem bons "caminheiros", "corajosos e próprios para o emprego das armas, e para a profissão marítima são na generalidade de compleição robusta e dotados de propensão natural; ... em muitos se descobre gênios para as artes mecânicas". ${ }^{14}$ Mesmo na Corte, havia um grande contingente de índios executando serviços domésticos a particulares "sem que recebam salario ou estipendio algum, achando-se assim reduzidos ao estado de quase perfeito cativeiro" (Freire, 2009, p.85).

Em muitas províncias destacou-se a participação indígena nos serviços de navegação, como remeiros e camaradas, com especial destaque para Goiás, Pará, Amazonas e Mato Grosso. Foram responsáveis também pela fabricação das canoas. O reconhecimento da especialidade canoeira dos indígenas amazônicos levou ao seu intenso recrutamento para o serviço da Marinha Imperial e mercante, já identificável na década de 1840. Muitas vezes, como destacou 
Vera Alarcón Medeiros (2006), a arregimentação ocorreu "sem o menor vexame", mascarando procedimentos de compra e venda daquela população. Ao retomar os pronunciamentos do ministro da Marinha, Holanda Cavalcanti que participou ativamente nos debates parlamentares sobre a formulação da política de Catequese e Civilização -, a autora demonstrou como os usos e abusos do trabalho indígena foram centrais em decisões imperiais:

Essas tribos errantes pelos sertões e matos do Brasil, que ao aproximarem-se das nossas povoações, requerem auxílios de alimentos e de insignificantes presentes; e que em troco deixam seus filhos e parentes expostos a uma quase servidão, poderão mui bem merecer todas as atenções e auxílios do Governo em suas pequenas necessidades, e serem chamados e empregados vantajosamente para eles e para o serviço da Marinha, em vez de se ocuparem em serviço de particulares, quase sempre interrompido, quer por mau tratamento, quer por falta de religiosa observância com os ajustes com eles celebrados, ou das promessas verbais a eles feitas. (Cavalcanti apud Medeiros, 2006, p.240-241)

O ministro relembrou o uso de indígenas nesse ramo de serviços em tempos anteriores, com "préstimo e aptidão", e concluiu que 2 mil seria um número apropriado para atender às demandas da Marinha brasileira e contribuir com a civilização da raça. Disse ainda que: "Para ser mais eficaz a disposição apontada a respeito dos indígenas para o serviço da Marinha, forçoso seria acompanhá-la da isenção do serviço privado" (Medeiros, 2006, p.241), quando não fosse uma demanda autorizada por instâncias superiores.

Holanda Cavalcanti, de uma vez só, demonstrou o conhecimento sobre a utilização da mão de obra indígena sem a observância de critérios legais por particulares, como também exprimiu a intenção do Estado em valer-se desse contingente especializado por um preço mais razoável do que vinha investindo. Vera Alarcón Medeiros apontou que, para Cavalcanti, a incorporação dos índios para a Armada Imperial se tratou de uma solução melhor que a contratação de marinheiros estrangeiros (europeus) que, de forma muito similar ao problema da colonização, não atingiu os resultados esperados em razão do não cumprimento dos contratos.

Nenhuma outra atividade absorveu mais a força de trabalho indígena do que os empreendimentos rurais. Essa constatação é unânime nos relatórios provinciais. Os índios do Império trabalharam em troca de salários nos povoados e fazendas circunvizinhos aos aldeamentos, tanto nas roças quanto nos campos de criação, sendo esta uma das principais razões do seu esvaziamento. 
Foi o que constatou o presidente do Espírito Santo em 1862: "os índios que deixaram os aldeamentos ocupam-se como jornaleiros nas fazendas de Itapemirim e em algumas de Minas". Ele também mencionou outro grupo de 48 índios residindo numa fazenda, "sendo aplicados aos trabalhos da lavoura". ${ }^{15}$ Em Minas Gerais, além de trabalhadores "à jornal” para os fazendeiros, um relatório de 1868 tratou do caso de 19 índios vivendo como agregados, "restos da aldeia do Casemiro", cuja trajetória remonta a 1819, além de uns quantos índios que foram mencionados estando sob a tutela daqueles que haviam participado da destruição de suas aldeias (a maioria da colônia militar de Urucu), portanto prisioneiros, aliás levados para o Rio de Janeiro. ${ }^{16}$

Como vimos, foi muito comum que fazendeiros filantropicamente amparassem grandes levas de população de origem indígena em suas terras e, dali, extraíssem braços para suas plantações ou criações. Para diversas autoridades o trabalho nas fazendas também se deu porque os aldeamentos não possuíam os recursos minimamente necessários às suas populações, levando seus moradores a buscar emprego para "sustento e vestuário", como disse uma autoridade mineira em $1867 .{ }^{17}$ A relação direta entre a capacidade dos aldeamentos de garantirem o sustento de suas populações e a dependência acarretada de tal carência com o mercado de trabalho circunvizinho foi tão óbvia, que estava prevista na lei de 1845. Era obrigação dos Diretores atentar para os recursos dos aldeamentos, de modo a "providenciar que não sobrevenha alguma fome, que seja causa de que os índios abalem para os matos ou se derramem pelas fazendas e povoações” (Art. $\left.1^{\circ}, \$ 25\right)$.

Entretanto, esse "aproveitamento da mão de obra indígena" não ocorreu de forma clara e respeitosa, como adiantara Holanda Cavalcanti, na década de 1840. O presidente da província do Amazonas confessou anos mais tarde que muitos Diretores de aldeamentos, não só em sua província, "supõem que o cargo lhes foi dado para ter trabalhadores com mais facilidade", e que sem grandes constrangimentos "por escrito sustentem que lhes cabe o direito de usufruir o serviço dos índios". ${ }^{18}$ Para os laboriosos indígenas não houve segurança sequer perante as autoridades, a quem competia o seu zelo, e que usufruíram do seu trabalho, muitas vezes, sem qualquer retribuição.

Na província do Pará, a presidência denunciou o total abuso sob o qual encontravam-se os índios perante os chamados regatões - comerciantes em embarcações fluviais -, que se inseriam nas aldeias do sertão para convencê-los a trabalhar na colheita de castanha, na extração de salsaparrilha e outros produtos nativos, "e quando passados 3 a 4 meses de árduo trabalho, regressa [o regatão] ao grêmio da aldeia, ele lhes faz a conta de modo que o mísero índio 
lhe fica devendo ainda" ${ }^{19}$ Leia-se: escravidão por dívidas. De acordo com muitas autoridades contemporâneas, a atuação dos regatões junto às populações indígenas teria sido fator de grande influência no fracasso das iniciativas de aldeamento nas províncias do Pará e Amazonas durante o século XIX. Esse entendimento atribuiu aos "quitandeiros dos rios" uma agência perversa perante o ingênuo natural que, desconhecedor pleno dos valores comerciais, trocou bens de altíssimo valor (como o látex e o guaraná) obtidos com considerável dispêndio de trabalho, por outros inigualáveis em um injusto comércio, ou ainda, com pagamento mediante bebidas alcoólicas (Henrique; Morais, 2014). Entretanto, os indígenas tinham muita clareza quanto à exploração que sofriam, visto que acionaram periodicamente as autoridades (em variadas instâncias: local, regional, nacional) denunciando os abusos sofridos (Dantas, 2018; Dornelles, 2017; Freire; Silva, 2017; Henrique; Morais, 2014; Melo, 2018; Silva, 2016).

Com tantos elementos, cabe questionar alguns aspectos da forma em que se deram as negociações sobre a mão de obra indígena nesse período. Certamente, não ocorreram de modo homogêneo. Fatores como diferenças regionais de produção, mercado e oferta de braços de outra sorte (escravos, libertos, brancos pobres, colonos mestiços e outras variantes de trabalhadores nacionais), o grau de adesão dos distintos grupos indígenas ao sistema de aldeamentos e os interesses indígenas na inserção no universo produtivo alheio, bem como a capacidade de atrair ou coibir esses trabalhadores, são pontos de partida para pensar o tema.

A questão do trabalho parece ter sido um locus privilegiado para a construção de identidades étnicas e políticas. O estudo mais apurado, nesse sentido, foi elaborado por Vânia Losada Moreira (2010), que se debruçou sobre o sistema de recrutamento de trabalho dos índios da província do Espírito Santo, mais especificamente os da vila indígena de Nova Almeida, entre os anos de 1828 e 1853, aplicando uma metodologia serial, ainda pouco explorada pelos historiadores dos índios no Brasil. Ela demonstrou a existência de um sistema político e administrativo voltado para a captação da mão de obra indígena cujo fim foi, sobretudo, o "serviço imperial e nacional". Tal modelo emergiu como resultado de uma condição jurídica, o relativo “autogoverno" indígena, decorrente da extinção do Diretório dos Índios (Carta Régia de 1798) e a inexistência, até a lei de 1845, de intermediários ou tutores, possibilitando que os índios assumissem cargos civis e militares nas Câmaras. O cargo de Capitão-mor foi assumido por principais, distribuindo a força de trabalho indígena. 
Para a autora, aquela parte do Império tangente à Corte era eminentemente indígena, fosse pela reconhecida presença dos Puri e Botocudo nas matas e sertões, fosse pela expressiva articulação na vida social e política dos indígenas das vilas, cujo passado remetia aos aldeamentos coloniais. A tipologia dos serviços identificados pela autora vão desde o corte de madeira, a construção naval, serviços de correio e trabalho doméstico, até alguns mais especializados, como a solicitação de índias "desembaraçadas", isto é, solteiras ou sem filhos, para a Santa Casa de Misericórdia nos cuidados de órfãos, o recrutamento para trabalhar no aldeamento de selvagens na Diretoria do Rio Doce como agricultores, o trabalho na construção civil e na defesa, a função de remeiros no Forte São João e Passagens, a captura de escravos fugitivos e o combate a quilombos (Moreira, 2010, p.26).

A análise da documentação mostrou, contudo, que esse sistema de organização do trabalho para o Estado e particulares, de origens coloniais, foi progressivamente caindo em desuso, à medida que se aproximava a década de 1840. Como atentamente destacado pela autora, é o "sistema governativo para gerir o trabalho dos índios que entra em colapso a partir da década de 1840, não o costume de os índios prestarem serviços ao Estado e aos particulares nem tão pouco a subordinação política deles ao governo municipal” (Moreira, 2010, p.28). Esse dado surgiu da constatação do arrefecimento do tema "trabalho" na série em questão, em detrimento de outros. Infelizmente, a pesquisadora não pôde se debruçar sobre as questões específicas do trabalho indígena para os particulares.

Então, a partir das alterações da legislação indigenista de 1845 e imperial de 1850 (Lei de Terras) podem-se observar algumas transformações nas formas de constrangimento legais e/ou costumeiras, e as possibilidades para administrar a mão de obra indígena. Ainda dialogando com o caso capixaba, um dos caminhos apontados por Moreira para essa inflexão foi o recrutamento militar compulsório, ancorado no argumento do caráter "vadio" daquela população de origem indígena. A falta de família e plantações, "ou que não tivessem um 'amo' ou 'patrão', fez com que os indígenas caíssem nas malhas do recrutamento por serem 'vadios', e passaram a servir na província ou na corte do Rio de Janeiro” (2006, p.29). A participação de indígenas em serviços militares foi sem dúvida uma constante em todo o período Imperial. Deu-se mediante recrutamento forçado, mas também pela iniciativa dos grupos indígenas que viam nas lutas do Estado - e naquelas contra ele - maneiras de garantir seus próprios interesses: sua integridade étnica, terras, sua liberdade. Entretanto, para os propósitos deste artigo não avançaremos nessas questões. 
Recuperemos os ditames do Regulamento das Missões sobre a força de trabalho indígena. A retomada de práticas oficiais de tutela por meio do estabelecimento do cargo de Diretor foi a primeira a ser mencionada. O mesmo se pode apreender da decisão de reabilitar a missão religiosa como medida de governo para populações indígenas. Haja vista todas as ressalvas feitas na tentativa de guardar diferenças com épocas pretéritas, podemos afirmar sem medo o compromisso com a formação de mão de obra que esse fato implicava.

A lei era clara. Já no segundo parágrafo do primeiro artigo das atribuições do Diretor requereu-se: "Indagar os recursos que oferecem para a lavoura, o comércio, os lugares em que estão colocadas as aldeias; e informar ao Governo Imperial sobre a conveniência de sua conservação, ou remoção, ou reunião de duas ou mais, em uma só”. Ora pois, a proximidade de aldeamentos dos centros produtivos era estratégia antiga, ainda mais somada ao estabelecimento de escolas de oficinas de artes mecânicas também previsto pela mesma lei (Art. $\left.1^{\circ}, \$ 26\right)$ e controladas pela atuação dos capuchinhos, visando a prestação de serviços públicos na realização de obras.

Mas, sobretudo, a lei era explícita quanto à vigilância que competia ao Estado, na figura do Diretor Geral, sobre o "não constrangimento dos índios para o serviço a particulares", inquirindo sobre o pagamento de jornais "quando chamados para o serviço da aldeia, ou qualquer serviço público; e em geral que sejam religiosamente cumpridos de ambas as partes os contratos que com eles se fizerem" (Art. $1^{\circ}, \S 28$ ). A distribuição do trabalho, de fato, cabia ao Diretor do aldeamento, fosse nas plantações, trabalhos coletivos ou qualquer serviço público - a lei traz mesmo a expressão "repartir o trabalho" (Art. $2^{\circ}, \S$ 5) - dando ainda mais provas de sua inspiração no passado colonial recente. Sobre o Diretor também recaíram as obrigações do Art. $1^{\circ}, \$ 28$. A produção e o consumo dos aldeamentos deveriam ser vigiados no intuito de controlar a sua indústria.

Dito isto, vejamos um exemplo de como acontecia a cooptação de trabalhadores indígenas nos sertões do Império. Em outubro de 1864, por conta de um episódio de conflito no sertão paulista, o Subdelegado de Polícia da vila de Botucatu, nosso interlocutor, quis se pronunciar sobre o que chamou fato de grande gravidade e assustadoras consequências. Ele rememorou às autoridades provinciais às quais se dirigiu que aquele horroroso ato era mais um da enorme lista dos que já havia a localidade sido cenário e, como morador dali de 8 para 9 anos, somaram-se pelo menos 50 vítimas (de não índios, claro). O pânico era tanto que "diversos moradores já se preparam a sair abandonando as propriedades e seus cômodos para buscarem em outros lugares 
segurança de vida". O despovoamento dos sertões tinha o potencial de causar tanto assombro quanto as investidas dos índios: em terras de posseiros, a ocupação tinha valor de título legal.

Porém, o que mais estarreceu os moradores daquelas bandas foi a veemente convicção de que os assaltos foram realizados por índios tidos como domesticados, aldeados no Salto Grande do Paranapanema, identificados majoritariamente como Kaingang. Aquele grande número de famílias, gente "desacostumada ao trabalho", sem lei nem governo, conhecedora de todos os tipos de vícios, "aglomerados em uma aldeia, não podem deixar de seguir a senda do crime para satisfazer as suas precisões". Para a autoridade local, os meios até aquele momento empregados em prol da catequese e civilização do indígena não eram "os mais condizentes e eficazes para conseguir o fim desejado". ${ }^{20}$ Conforme as indagações feitas sobre o caso, colhidas pelo Subdelegado de polícia de São Domingos, tratara-se mesmo de ações dos índios já catequisados, "e que para fazerem esses delitos e roubos usam de disfarce". ${ }^{21}$

As provas de que eram os índios mansos do aldeamento os desordeiros consistiram no uso de roupas por parte deles, embora usassem "de disfarce a nudez", e por conversarem "pela nossa linguagem". Outro indício era que se encontrassem no aldeamento os objetos furtados nos assaltos e reconhecidos pelos proprietários. Essas informações, o delegado tomou de dez testemunhas, habitantes do Alambary, sendo três delas vizinhas do Salto Grande. Entre elas, Camilo Soares de Siqueira, o qual contou que fora ao local22

ajustar alguns indios para lhe trabalharem, e que chegando na beira do rio deu um tiro, sinal costumado de aviso para os índios que moram além do rio virem à fala; e que dado este sinal tocaram buzina, sinal de reunião entre eles, que se reunindo aí apareceu um índio de nome João Pedro, e disse-lhe que não deixaria mais ninguém sair para trabalhar, e ali, d’ora em diante, não havia mais índios mansos, e que todos eram bravos, tanto que só esperavam chegar um Capitão de nome Raphael, que breve esperavam chegar do Paraná, o qual, sendo homem valoroso, com ele e seu reforço, haviam de reivindicar os seus terrenos, que como tais consideravam desde a Freguesia de São Domingos até os confins do Sertão, mas que apesar disso, por muita instância, lhe cedeu dez camaradas.

As riquíssimas informações apresentadas pela testemunha do Delegado nos possibilitam compreender de forma um pouco mais aprofundada o que se passava no Paranapanema, para além das mútuas agressões entre civilizados nos sertões. O primeiro elemento que devemos destacar é a questão do 
trabalho. Uma vez mais podemos contrariar a ideia de que os índios não se prestavam ao trabalho. Como vimos, era costume recrutá-los para toda obra, principalmente para as roças. Sabendo do valor de sua mão de obra, o informante indígena declarou que não mais se disponibilizariam a esses serviços e, ainda assim, por muita instância, dez camaradas foram cedidos a Camilo Soares de Siqueira, do que se pode supor, como disse o índio - estavam todos bravos. Camilo deve ter implorado pelo acesso àqueles trabalhadores. Aquele aglomerado de gente não era, enfim, tão desacostumado ao trabalho como protestou o Subdelegado de Botucatu. O que incomodou de fato foi a presunção dos índios, que em tempos de carência de braços para a lavoura e expressivos gastos com importação de mão de obra estrangeira, negaram-se a incorporar o contingente de trabalhadores nacionais. Mesmo quando os empregadores em potencial usurparam suas terras e mataram suas famílias, além de criminalizarem suas tentativas de sobrevivência.

Os indígenas aldeados foram abordados pelo contratante de serviços em seus domínios, mas as negociações ocorreram por intermédio de apenas um representante indígena de nome João Pedro. Este deixou clara a tensão entre as partes, retomando aspectos referentes ao conflito sobre as terras, provavelmente, terrenos ocupados por fazendas onde terminaram por labutar. Como já destacamos, aquele intermediador - uma possível liderança - reconheceu a necessidade de braços para lavoura que os moradores tinham e, portanto, a dependência destes para com os índios. Ao professar o término do suprimento de mão de obra, atendendo à postura suplicante de Camilo Soares de Siqueira para angariar dez trabalhadores, João Pedro indicou uma correlação de poder em favor dos índios do Salto Grande.

Um caso de semelhança notória foi observado por Izabel Missagia de Mattos (2004, p.13) em seu estudo sobre a catequese dos Botocudos na província mineira. O Diretor Geral dos Índios, Manuel Joaquim de Lemos, identificou como insubordinação a postura dos índios, outrora mansos, dos aldeamentos de Ponté e Pontorá, no vale do rio Mucuri, no final dos anos 1860. Segundo ele, "Estes aldeamentos eram mansos, pacíficos e relacionados com a população do lugar, a quem prestaram seus serviços, fazendo também para si alguma coisa, mas são tratados como escravos naqueles lugares, e pessoas há que com o trabalho dos índios plantam de 6 a 8 alqueires de milho, sem pagar-lhes cousa alguma". ${ }^{23}$

Os aldeamentos em questão concentravam uma significativa população, estimada entre 300 a 400 pessoas que, conforme a autoridade, foram os braços das fazendas próximas. Acontece, porém, que a forma de trabalho praticada 
foi ilegal: assemelhou-se à escravidão tanto pelo esforço extensivo quanto pela falta de quitações. Aquela situação toda foi agravada pela decisão do Diretor dos aldeamentos de estabelecer uma diária no valor de 320 réis para o uso dos serviços dos índios pelos moradores, tendo em vista "evitar o mau trato de que eram vítimas os índios". Também incumbiu o língua Manuel Francisco da Fonseca da organização das "férias do serviço". A subversão dos índios considerados já civilizados - posto que eram mansos - ao costume do trabalho coercitivo resultou em retaliações no mínimo selvagens dos que se viram prejudicados: atacaram o aldeamento de Pontorá, expulsando as famílias e assassinando duas pessoas, além de se apoderarem "de toda a criação e mantimentos". O Diretor e as autoridades judiciais procederam aos indicativos do Regulamento das Missões, indiciaram e processaram os criminosos. Contudo, reclamavam a falta de "força pública para cativá-los", motivo pelo qual "continua ainda insubordinada a mesma aldeia” (Mattos, 2004, p.113).

Como no Salto Grande do Paranapanema em anos anteriores, os indígenas do vale do Mucuri estavam bravos. Para eles, o reconhecimento de sua disposição para o trabalho nas lavouras pelos seus patrões era fundamental, pois apresentava-se como maneira de impor limites nessa relação. Embora existisse todo um aparato legal para impedir a exploração no uso da mão de obra indígena e houvesse alguns interessados em não tornarem tais leis letras mortas, os posseiros fizeram largo uso da violência para sobrepor seus projetos. Nos anos 1870, frisou Mattos, o interesse na mão de obra indígena do Mucuri os manteve mobilizados, num "estado de indisciplina assustador" para retomar as palavras do Diretor daquela zona. Nesse tempo, os mesmos posseiros que haviam acometido o aldeamento em 1868, "com inteira infração da lei de terras, introduziram-se na mata e tomaram posição nas imediações do grande aldeamento do Pontorá. Escravizando completamente os índios, deles se tem servido não só para os seus trabalhos rústicos, como ainda para instrumento de seus crimes" (Mattos, 2004, p.114).

Ao observar alguns exemplos de como se deu a aquisição da mão de obra indígena no Império, podemos verificar que coexistiram sistemas de trabalho negociado e de exploração compulsória e não remunerada, em analogia à condição de escravidão, conforme testemunhos contemporâneos. Para o primeiro tipo de cooptação de mão de obra as partes interessadas puderam explorar condições variáveis de dependência mútua nessas novas zonas de povoamento, os sertões, e assim recolocaram, momento a momento, o equilíbrio de poder. Uma verdadeira surpresa! - não para os índios, obviamente: algumas vezes foram as populações indígenas que ditaram os ritmos de trabalho, as 
circunstâncias nas quais se disponibilizariam, as formas de pagamento. Fizeram isso movidos por necessidades e interesses próprios, nem sempre compatíveis com as regras econômicas estabelecidas. Nas fazendas, o trabalho indígena caracterizou-se pela sazonalidade. Não se tem notícias, até o presente, da formalização de contratos com essas populações; tratou-se de um mercado circunstancial, no qual era possível entrar e sair, no sentido da não proletarização dessas pessoas. Dito isso, é preciso fazer a ressalva de que, mesmo quando negociadas, as condições de trabalho dos indígenas sempre foram muito instáveis, podendo facilmente transformar-se em coerção.

O segundo tipo resultou amplamente de um paradoxo: a incapacidade e o concomitante êxito do Estado brasileiro em fazer cumprir leis. Não por acaso, essa leitura sobre a política imperial a respeito do trabalho indígena remete à análise apresentada por Sidney Chalhoub em A força da escravidão: ilegalidade e costume no Brasil oitocentista (2012). O historiador aprofundou a compreensão sobre o tema da precariedade da experiência de liberdade de negros livres e pobres, que tinham a vida orientada pela escravidão, podendo sempre assumir ou retornar a essa condição, por meio da análise "da intrincada engenharia institucional e política" que possibilitou a escravização "ao arrepio da lei” de milhares de pessoas, mesmo após a lei de 7 de novembro de 1831 que determinou a proibição do tráfico africano de escravos. O autor percorreu os caminhos da burocracia imperial, dos pormenores da administração pública, das ações do Judiciário, e os resultados dessas práticas no cotidiano das relações escravistas, destacando o aprendizado, nos mais diversos níveis, das formas de desviar da lei (Chalhoub, 2012, p.30).

O que quero aqui sugerir ao leitor é a lembrança de que tanto as políticas quanto as práticas para manter em funcionamento o sistema ilegal de escravização de africanos e libertos, depois de 1831, foram arbitradas pelos mesmos homens, ou por boa parte deles, os quais determinaram outras tantas políticas e práticas para os índios, terras e colonização - explicitados nas leis de 1845 e $1850 .{ }^{24}$ Porém, ao tratar do assunto do trabalho indígena fica evidente outra possibilidade de aproximação: a precariedade da liberdade indígena. Por coincidência de data e matéria, a última lei brasileira que tratou explicitamente da escravidão de índios foi a de 27 de outubro de 1831, revogando as Cartas Régias de 1808, que permitiram a escravização temporária dos índios aprisionados em guerra justa. O Regulamento das Missões (1845) não apresentou o termo, mas sim, que se deveria "Exercer toda a vigilância em que não sejam os índios constrangidos a servir a particulares..." (Art. $1^{\circ}, \S 28$ ). Portanto, o estatuto 
jurídico do índio durante o período oitocentista condicionou ao mesmo tempo a proibição e a causa de sua escravização.

Como vimos nos exemplos aqui tratados, foram inúmeras as vezes em que as populações indígenas tiveram sua liberdade tolhida ou ameaçada. Os casos apresentados são certamente uma ínfima parte do conjunto total de pessoas que, no século XIX, experimentaram tal condição em virtude de sua origem indígena. Como pontuado pelo historiador da escravidão indígena, Andrés Reséndez (2016, p.5), a falta de estimativas numéricas sobre o tema reside no fato de esta "outra escravidão" ter sido quase sempre ilegal, "suas vítimas tolhidas, literalmente, em cantos escuros e trancadas atrás das portas, nos dando a impressão de que elas eram menores do que na verdade eram". O estudo de Reséndez consiste em uma abordagem transnacional e de longa duração sobre a problemática da escravidão indígena, seguindo uma linha cronológica a partir das primeiras experiências escravocratas sobre povos da América no Caribe e acompanhando seu processo de amplificação geográfica e aumento de complexidade até meados do século XIX no Oeste norte-americano. Assim, podem-se estabelecer analogias para o problema no Oitocentos brasileiro. Para aquele autor, a definição de escravidão indígena é de difícil apreensão, mas alguns pontos são observáveis:

Inicialmente, a escravidão indígena era legal, e, portanto, as vítimas desse tráfico eram claramente rotuladas como escravos na documentação. Mas depois da proibição da escravização indígena pela coroa espanhola, os proprietários recorreram a uma variedade de arranjos de trabalho, termos e subterfúgios - como encomiendas, repartimientos, convict leasing [trabalho penal, comum no sul dos Estados Unidos], debt peonage [escravidão por dívidas], para contornar a lei. Apesar de ser impossível essas formas de trabalho caberem em uma definição única, elas geralmente compartilhavam quatro traços que as tornavam semelhantes à escravidão: remoção forçada das vítimas de um lugar para outro, incapacidade de deixar o local de trabalho, violência ou ameaça de violência para obrigar a trabalhar e remuneração nominal ou não pagamento. (Reséndez, 2016, p.10)

No Brasil, a escravização de indígenas no período colonial foi marcada pela inconstância quanto à legalização desta prática, tendo produzido efeitos tanto sobre as populações indígenas quanto na própria constituição das sociedades e economias coloniais. A prática da escravização de índios por bandeirantes na São Paulo colonial (séculos XVI e XVII), de acordo com John Monteiro (1994), demonstrou como a ilegalidade fez parte da formação das estruturas sociais e da 
elaboração de uma mentalidade escravista. Como esse autor explicou, "a venda de índios que não fossem tomados em guerras justas constituiu um ato manifestadamente ilegal, mesmo dentro dos mal definidos contornos da legislação indigenista" (Monteiro, 1994, p.77). Para ele, o caso da administração particular denunciou a precariedade da liberdade de indígenas descidos dos sertões e aldeados, e também da minoria não reduzida e aldeada.

Ao formar aldeamentos, a mão de obra dos índios passou a ser alvo de uma intensa disputa de interesses. Os jesuítas reclamaram a autoridade sobre a distribuição/repartição do trabalho dos índios para serviços periódicos; já os colonos desejavam manter para si o controle direto dessa administração. Para tanto, fizeram grande uso das Câmaras Municipais no intuito de driblar medidas legislativas, alegando o costume como fonte para justificar a contravenção (Monteiro, 1994, p.131-132). ${ }^{25}$ Desse modo, ao se tomar os indígenas como incapazes de administrar a si mesmos, os colonos, enquanto administradores de índios, "produziram um artifício no qual se apropriaram do direito de exercer pleno controle sobre a pessoa e propriedade dos mesmos sem que isso fosse caracterizado juridicamente como escravidão" (Monteiro, 1994, p.137). No presente artigo podemos ver uma face indígena do processo de construção de uma sociedade escravista cujo aprendizado sobre condutas ilegais no período colonial mostrou grande força no período imperial.

No século XIX, despois de uma nova onda de escravização indígena juridicamente amparada nas Cartas Régias de 1808, reabilitando a guerra justa e o cativeiro, e sua revogação em 1831, optou-se, definitivamente, pelo silêncio normativo quanto ao tema. Como pudemos observar nos exemplos tratados anteriormente, a ilegalidade da escravidão indígena distava concretamente da realidade corriqueira de mantê-los em condições precárias de trabalho, servis ou, finalmente, como escravos. Depois de tudo isso, é mesmo impressionante a força que tomou o discurso sobre a desqualificação para o trabalho da população indígena. $\mathrm{O}$ peso dado à diferença cultural certamente contribuiu para esse preconceito. À apropriação ilegal da mão de obra indígena somava-se a expropriação de suas terras; conjugados, os dois processos aumentavam as chances de esses despossuídos serem obrigados ao trabalho em condições desfavoráveis. Perante essa situação, as populações indígenas buscaram caminhos diversos para garantir sua liberdade, fosse pelo uso constante dos artifícios legais, reclamando às autoridades nas Câmaras, presidências provinciais e na Corte, ou através da adesão ao projeto de aldeamentos. Novos estudos ainda mostrarão o quanto os processos de descaracterização de grupos étnicos e a 
fragilidade política de sua condição jurídica também se apresentaram para eles como caminhos para alcançarem sua liberdade.

\section{REFERÊNCIAS}

ALMEIDA, Maria Regina C. de. Metamorfoses indígenas: identidade e cultura nas aldeias coloniais no Rio de Janeiro. Rio de Janeiro: Arquivo Nacional, 2003.

Política indigenista e etnicidade: estratégias indígenas no processo de extinção das aldeias do Rio de Janeiro, século XIX. Anuario IEHS, v. sup. 1, p.219-233, 2007.

AMOROSO, Marta Rosa. Catequese e evasão: etnografia do Aldeamento Indígena São Pedro de Alcântara, Paraná (1855-1895). Tese (Doutorado em Antropologia) Faculdade de Filosofia, Letras e Ciências Humanas (FFLCH), Universidade de São Paulo (USP). São Paulo, 1998.

CHALHOUB, Sidney. A força da escravidão: ilegalidade e costume no Brasil oitocentista. São Paulo: Companhia das Letras, 2012.

CUNHA, Manuela Carneiro da. Legislação indigenista no século XIX: uma compilação: 1808-1889. São Paulo: Comissão Pró-Índio de São Paulo, 1992a.

. Política indigenista no século XIX. In: CUNHA, Manuela Carneiro da (Org.) História dos Índios no Brasil. São Paulo: Companhia das Letras; Secretaria Municipal de Cultura; Fapesp, 1992b. p.133-154.

DANTAS, Mariana Albuquerque. Do aldeamento do Riacho do Mato à Colônia Socorro: defesa de terras e aprendizado político dos indígenas de Pernambuco (18601880). Revista Brasileira de História, São Paulo: Anpuh, v.38, n.77, p.81-102, 2018.

DORNELLES, Soraia Sales. De Coroados a Kaingang: as experiências vividas pelos indígenas no contexto de imigração alemã e italiana no Rio Grande do Sul do século XIX e início do XX. Dissertação (Mestrado em História) - Universidade Federal do Rio Grande do Sul (UFRGS). Porto Alegre, 2011.

A questão indígena e o Império: índios, terra, trabalho e violência na província paulista, 1845-1891. Tese (Doutorado em História) - Instituto de Filosofia e Ciências Humanas (IFCH), Universidade Estadual de Campinas (Unicamp). Campinas, 2017.

FREIRE, José Ribamar B. Aldeamentos indígenas do Rio de Janeiro. Rio de Janeiro: Ed. Uerj, 2009.

FREIRE, José Ribamar B.; SILVA, Ana Paula da. Protagonismo e diplomacia indígena no século XIX. Habitus, Goiânia, v.15, n.1, p.55-72, jan./jun. 2017.

HENRIQUE, Márcio Couto; MORAIS, Laura Trindade de. Estradas líquidas, comércio sólido: índios e regatões na Amazônia (século XIX). Revista de História. São Paulo, n.171, p.49-82, jul./dez. 2014. 
KODAMA, Kaori. Os índios no império do Brasil: a etnografia do IHGB entre as décadas de 1840 e 1860. Rio de Janeiro: Ed. Fiocruz; São Paulo: Edusp, 2009.

MALHEIRO, Perdigão. A escravidão no Brasil: ensaio histórico, jurídico e social. $2^{\text {a }}$ parte. Rio de Janeiro: Typographia Nacional, 1867.

MATTOS, Izabel Missagia de. Civilização e revolta: os Botocudos e a catequese na província de Minas. Bauru: Edusc, 2004.

MEDEIROS, Vera Alarcón. Incompreensível colosso: a Amazônia no início do segundo reinado (1840-1850). Tese (Doutorado) - Departamento de Antropología Cultural e Historia de América y Africa, Universidad de Barcelona. Barcelona, 2006.

MELO, Karina Moreira R. da S. e. A aldeia de São Nicolau do Rio Pardo: identidades indígenas em construção. In: REMEDI, J. (Org.) Na fronteira do império: política e sociedade na Rio Pardo oitocentista. Santa Cruz do Sul: Edunisc, 2018. p.12-36.

MONTEIRO, John M. Negros da terra: índios e bandeirantes nas origens de São Paulo. São Paulo: Companhia das Letras, 1994.

MOREIRA, Vânia Maria L. Caboclismo, vadiagem e recrutamento militar entre as populações indígenas do Espírito Santo (1822-1875). Diálogos Latinoamericanos, Dinamarca: Aarhus Universitet, n.11, p.94-120, 2006.

A serviço do império e da nação: trabalho indígena e fronteiras étnicas no Espírito Santo (1822-1860). Anos 90, Porto Alegre, v.17, n.31, p.13-55, jul. 2010.

OLIVEIRA, João Pacheco de (Org.) A viagem de volta: etnicidade, política e reelaboração cultural no Nordeste indígena. Rio de Janeiro: Contracapa, 1999.

PERRONE-MOISÉS, Beatriz. Índios livres e índios escravos: os princípios da legislação indigenista do período colonial (séculos XVI a XVIII). In: CUNHA, Manuela Carneiro da (Org.) História dos índios no Brasil. São Paulo: Companhia das Letras, 1992. p.115-132.

RESÉNDEZ, Andrés. The Other Slavery: The Uncovered Story of Indian Enslavement in America. Boston; New York: Houghton Mifflin Harcourt, 2016.

SAMPAIO, Patrícia. Nos confins do Império: diversidade e etnicidade no mundo do trabalho na Amazônia do século XIX. In: XAVIER, Giovana (Org.) Histórias da escravidão e do pós-abolição para escolas. Belo Horizonte: Fino Traço; Rio de Janeiro: MC\&G; Brasília: MEC, 2015. p.179-194.

SILVA, Ayalla Oliveira. Ordem imperial e aldeamento indígena: Camacãs, Gueréns e Pataxós no sul da Bahia. Ilhéus: Editus, 2017.

SILVA, Edson. Índios organizados, mobilizados e atuantes: história indígena em Pernambuco nos documentos do Arquivo Público. Revista de Estudos e Pesquisas, Brasília: Funai, v.3, n.1/2, p.175-224, jul./dez. 2016. 
SPOSITO, Fernanda. Nem cidadãos, nem brasileiros: indígenas na formação do Estado nacional brasileiro e conflitos na província de São Paulo (1822-1845). São Paulo: Alameda, 2012.

WITTMAN, Luisa Tombini. O vapor e o botoque: imigrantes alemães e índios Xokleng no Vale do Itajaí/SC (1850-1926). Florianópolis: Letras Contemporâneas, 2007.

\section{NOTAS}

${ }^{1}$ Este artigo é uma versão modificada de partes dos capítulos 2 e 4 de minha tese de doutorado, cuja pesquisa foi financiada pelo CNPq. Agradeço as sugestões da banca e os comentários e revisão realizados por José Juan Pérez Meléndez, Karina Melo e Ivânia Susin. Agradeço também aos pareceristas da Revista Brasileira de História pelos comentários e sugestões.

${ }^{2}$ Arquivo Público do Estado de São Paulo (APESP). Repositório Digital (RD). Ofícios Diversos (OD). 30 maio 1853. Para a tabela completa ver: DORNELLES, 2017, p.75.

${ }^{3}$ APESP. RD. OD.13 abr. 1853.

${ }^{4}$ As referências ao texto do Regulamento acerca das Missões de Catequese e Civilização de Índios (1845) foram extraídas de CUNHA, 1992a, p.191-199.

${ }^{5}$ APESP. RD. OD. 27 fev. 1847.

${ }^{6}$ Sobre o tema da descaracterização das populações dos aldeamentos no XIX consultar: OLIVEIRA, 1999; ALMEIDA, 2007. Conforme esses autores, a descaracterização étnica se dá, principalmente, por conflitos territoriais. Assim, extinguir as aldeias nos termos legais significava a incorporação de suas terras.

${ }^{7}$ APESP. RD. OD. 10 mar. 1847.

${ }^{8} \mathrm{~A}$ intenção aqui foi chamar a atenção para a persistência do costume no trato com a população indígena quando o assunto é o seu trabalho. A ampliação das pesquisas sobre o tema no período imperial deve dar suporte a análises mais aprofundadas, contudo, o que observamos na experiência paulista aponta para a continuidade e naturalização de práticas ilegítimas de obrigá-los ao trabalho. Para uma análise geral da legislação indigenista no período ver: CUNHA, 1992b, p.133-154. Sobre a escravidão indígena na São Paulo colonial consultar: MONTEIRO, 1994, cap. 4.

${ }^{9}$ APESP. RD. OD. 2 jan. 1854.

${ }^{10}$ APESP. RD. OD. 16 out. 1854.

${ }^{11}$ Sobre a prática indígena de obter objetos de metal, tecidos etc. e suas finalidades no XIX consultar: DORNELLES, 2011; WITTMAN, 2007.

${ }^{12}$ Foram consultados todos os relatórios disponíveis em http://www-apps.crl.edu/brazil/ provincial dos anos de 1862, 1866 e 1867, e para algumas províncias em anos aleatórios na 
década de 1860 . No ano de 1861, correu uma circular que solicitou dos governos provinciais relatórios circunstanciados sobre o Serviço da Catequese e Civilização.

${ }^{13}$ Relatório Presidente Província (RPP) AL, 1862, p.17 do Anexo.

${ }^{14}$ Ibidem, p.5.

${ }^{15}$ RPPES, 1862, p.54.

${ }^{16}$ RPPMG, 1868. Anexo 15, p.2.

${ }^{17}$ RPPMG, 1867, Anexo II, p.1.

${ }^{18}$ RPPAM,1862, p.15.

${ }^{19}$ RPPPA, 1862, p.12-22.

${ }^{20}$ APESP. Fundo Polícia. Manuscritos. 1864. CO2502, CX-67. Maço Delegados Dezembro.

${ }^{21}$ APESP. Fundo Polícia. Manuscritos. 1864. CO2506, CX-71.

22 Ibidem.

${ }^{23}$ RPPMG, 1868. Anexo 15, p.2.

${ }^{24}$ Sobre os debates parlamentares e a questão indígena ver: DORNELLES, 2017, cap. 1; SPOSITO, 2012, cap. 2; KODAMA, 2009. Sobre as aproximações entre as condições dos trabalhadores indígenas e de africanos livres consultar: SAMPAIO, 2015.

${ }^{25}$ Sobre disputas pela mão de obra indígena nos aldeamentos coloniais ver: ALMEIDA, 2003.

Artigo recebido em 15 de fevereiro de 2018.

Aprovado em 27 de agosto de 2018.

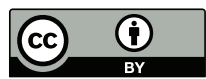

